Gamze Yücel Işıldar, A. Çağlan Günal*, Duygu Şahin, Burcu Kocak Memmi and Aylin Sepici Dinçel

\title{
How potential endocrine disruptor deltamethrin effects antioxidant enzyme levels and total antioxidant status on model organisms
}

\section{Potansiyel Endokrin Bozucu Deltametrin, Model Organizmalarda Antioksidan Enzim Düzeylerini ve Toplam Antioksidan Durumu Nasıl Etkiler}

https://doi.org/10.1515/tjb-2019-0382

Received September 25, 2019; accepted November 21, 2019; published online April 23, 2020

\section{Abstract}

Objective: Deltamethrin, synthetic pyrethroid, is a suspected endocrine disruptor contaminating ecosystems as toxic pollutant via agricultural activities and vector controls. The objective of the study is to determine the possible effects on human by evaluating antioxidant enzyme levels and total antioxidant status (TAS) of invertebrate model organism crayfish exposure to sublethal deltamethrin.

Materials and methods: Crayfish were exposed to $0.05 \mu \mathrm{g} /$ $\mathrm{L}$ deltamethrin for $48 \mathrm{~h}$ and 7 days. Hemolymph samples were taken for TAS and total haemocyte counts (THCs). Gill, hepatopancreas and muscle tissues were examined for superoxide dismutase (SOD), glutathion peroxidase (GPx) and catalase (CAT) enzyme activities.

Results: THCs were decreased $(\mathrm{p}<0.05)$ and hemolymph TAS levels were increased according to control groups. Gill SOD, CAT and GPx enzyme activities were significantly rised. Hepatopancreas SOD activities unchanged. Hepatopancreas

*Corresponding author: A. Çağlan Günal, Department of Biology Education, Gazi Education Faculty, Gazi University, Teknikokullar, Ankara, Turkey, E-mail: caglangunal@gazi.edu.tr

Gamze Yücel Işıldar: Department of Environmental Sciences, Graduate School of Natural and Applied Sciences, Gazi University, Ankara, Turkey

Duygu Şahin: Department of Biochemistry, Faculty of Medicine, İstanbul Aydin University, İstanbul, Turkey

Burcu Kocak Memmi: Insecticide Test Lab., Hacettepe University, Ankara, Turkey

Aylin Sepici Dinçel: Department of Medical Biochemistry, Faculty of Medicine, Gazi University, Ankara, Turkey
CAT activities were increased significantly after $48 \mathrm{~h}(\mathrm{p}<0.05)$, but returned back to controls after 7 days. Hepatopancreas GPx and muscle SOD activities were rised $(\mathrm{p}<0.05)$, while muscle CAT and GPx values did not affect from deltametrin.

Conclusion: Deterioration of ecosystems are directly affect the humans. The toxic effects of deltamethrin for different stages of organisms on the food web will provide basic data to understand and estimate the effects on the human beings.

Keywords: antioxidant enzymes; invertebrate model organism; synthetic pyrethroid; total antioxidant status; total haemocyte counts

Öz

Amaç: Sentetik piretroid olan deltametrin tarmmsal aktivite ve vektör kontrolü sonucu ekosisteme bulaşan ve endokrin bozucu etkisi olduğu şüphelenilen bir toksik kirlticidir. Bu çalışmanın amacı, omurgasız model organizma tatl su istakozlarının subletal deltametrine maruziyetlerinin antioksidan enzim düzeyleri ve toplam antioksidan durumuna (TAS) etkileri belirlenerek insan üzerindeki olası etkileri değerlendirilecektir.

Gereç ve Yöntem: Tatlı su istakozları 48 saat ve seven gün süreyle $0.05 \mu \mathrm{g} / \mathrm{L}$ deltametrine maruz birakıldı. TAS ve toplam hemosit sayıları (THS) için hemolenf örnekleri alındı. Solungaç, hepatopankreas ve kas dokuları süperoksit dismutaz (SOD), glutatyon peroksidaz (GPx) ve katalaz (CAT) enzim aktiviteleri açısından incelendi.

Bulgular: Kontrol gruplarına göre THC'ler azalırken $(\mathrm{p}<0.05)$ ve hemolenf TAS düzeyleri arttı. Solungaç SOD, CAT ve GPx enzim aktiviteleri istatistik olarak önemli ölçüde artmıştır $(\mathrm{p}<0.05)$. Hepatopankreas SOD aktiviteleri değişmedi. Hepatopankreas CAT aktiviteleri 48 saat sonra önemli ölçüde artarken ( $p<0.05$ ), seven gün sonra kontrol değerlerine geri dönmüştür. Hepatopankreas GPx ve kas 
SOD aktiviteleri artarken $(\mathrm{p}<0.05)$, kas CAT ve GPx değerleri deltametrinden etkilenmemiştir.

Sonuçlar: Ekosistemlerin bozulması insanları doğrudan etkilemektedir. Besin ağında farklı trofik düzeyde organizmalarda deltametrinin toksik etkileri, insanlar üzerindeki etkilerini anlamak ve tahmin etmek için temel veriler sağlayacaktır.

Anahtar kelimeler: antioksidan enzimler; omurgasız model organizma; Sentetik piretroid; toplam antioksidan statü; toplam hemosit sayısı.

\section{Introduction}

Water bodies are frequently subjected to endocrine disruptors related to anthropogenic activities like agriculture, inducing a contamination by rain water and surface runoff containing various chemicals such as pesticides [1]. Pyrethroids, one of the widely used pesticides, have demonstrated viable representative for organochlorined, organophosphated and carbamate ones owing to being high bio efficiency, biodegradability and relatively less toxic for higher vertebrates [2]. The synthetic pyrethroid, deltamethrin ((S)o-cyano-3-phenoxybenzyl-(1R)-cis-3-(2.2-dibromovinyl)-2,2-imethylcyclopropanecarboxylate) has widely applied for crop protection, control of malaria and other vector borne diseases [3-5].

The toxic activity of deltamethrin is primarily at the voltage dependent sodium channels of the nerve cell membranes and inducing the neurotoxicity [6]. In addition to neurotoxic effects, the oxidative stress related to deltamethrin also induces toxic effects like other pesticides [713]. Oral application of $5 \mathrm{mg} / \mathrm{kg}$ of deltamethrin to mice induced oxidative stress and activated the mitochondrial pathway of apoptosis [14].

Freshwater crayfish, an alternative model organism to vertebrates for the assessment of environmental contaminants as a nontarget species, are important bioindicator organisms for water quality of freshwaters bodies [15]. The narrow-clawed crayfish, Astacus leptodactylus, is an ecologically important species in Eurasian freshwater bodies; has important role at the aquatic food webs in diverse water bodies and evaluating ecotoxicological risks [16].

In their study, although Meng et al. [17] determined motor axon activity and neuromuscular transmission effects of deltamethrin, no data was available about the effects of deltamethrin on the antioxidant enzyme levels and total antioxidant status (TAS) of crayfish. However, the effects of deltamethrin were studied in vertebrate organisms, very limited data were found for invertebrate organisms. The present study aimed to assess the antioxidant enzyme levels (SOD, CAT and GPx) on different vital organs with TAS and total haemocyte counts (THCs) for the haemolymph of crayfish (A. leptodactylus Eschscholtz 1823) after exposure to deltamethrin, a synthetic pyrethroid pesticides, contaminating aquatic environments as toxic contaminant of agricultural activities. The recent study will give an insight to the literature about the antioxidant and oxidant levels of related invertebrate species.

\section{Materials and methods}

\section{Experimental organism}

The narrow clawed freshwater crayfish (A. leptodactylus Eschscholtz, 1823), invertebrate model organism, was used as representative organism of fresh water ecosystems. Live organisms $(\mathrm{N}=128)$ were obtained from a fisherman during the fishing season. The mean weight and the length of crayfish were $30.57 \pm 5.26 \mathrm{~g}$ and $10.64 \pm 0.48 \mathrm{~cm}$, respectively.

\section{Test chemical}

Deltamethrin (China, Changzhou Kangmei Chem. Ind.Co. Ltd.), technical grade (98\%) was used in the experiment and obtained from the Hacettepe University Insecticide Test Lab. The stock solution was dissolved in DMSO and stored at $+4{ }^{\circ} \mathrm{C}$ till the dosing time.

\section{Acclimatisation period and experimental design}

Crayfish were acclimatised to laboratory medium for fifteen days before the trials and were fed with fresh trout during that period. Cleaning of the tanks were done twice in a day and the tanks were aerated constantly. All experiments were carried out according to the rules of "Guide for the Care and Use of Laboratory Animals" published by the US National Institutes of Health (NIH publication No. 85-23, revised 1996). After adaptation period, crayfish were stocked to experimental aquariums containing with $100 \mathrm{~L}$ of dechlorinated tap water. Animals were selected randomly for control and experiment groups, each stocked as 16 crayfish/8 aquaria's. The water composition was: $\mathrm{DO}_{2} 6.96 \pm 0.10 \mathrm{mg} / \mathrm{L} ; \mathrm{pH}=7.74 \pm 0.03$; conductivity $0.298 \pm 0.01 \mathrm{mS} / \mathrm{cm}$. Sublethal deltamethrin concentration was selected as the $1 / 10$ of $96 \mathrm{~h}$ LC50 values, $0.05 \mu \mathrm{g} / \mathrm{L}$. The stability of deltamethrin concentrations in the aquarium water was provided by renewing every $48 \mathrm{~h}$. Exposure lasted for one week. Haemolymph and tissue samples were taken after $48 \mathrm{~h}$ and 7 days.

\section{Haemolymph sampling and analysis}

Following the exposure to deltamethrin, haemolymph was taken on the base of the 2nd walking leg under ice anaesthesia using disposable syringe. Hemolymph samples were used for counting the total haemocytes and TAS determinations. THCs were performed with Thoma counting chamber according to Benli [18].

After haemolymph samples were centrifuged at 3,500 rpm, $10 \mathrm{~min}$ at $4^{\circ} \mathrm{C}$, TAS $(\mathrm{mmol} / \mathrm{L})$ were determined by a Randox 
commercial kits (Randox Laboratories Ltd., Crumlin, UK). The principle of the assay is incubating 2,2'-azinobis (3-ethylbenzothiazoline 6sulfonate) (ABTS) with ferrylmyoglobin radical, formed by the activation of a peroxidase (metmyoglobin) with hydrogen peroxide $\left(\mathrm{H}_{2} \mathrm{O}_{2}\right)$, to produce the radical cation ABTS+ [19].

\section{Tissue sampling and analysis}

Crayfish were sacrificed under ice anaesthesia and tissues were dissected; gill, muscle and hepatopancreas tissue samples were taken and stored for antioxidant enzyme analysis at $-80^{\circ} \mathrm{C}$.

\section{Superoxide Dismutase Activity (SOD)}

SOD activity was done by the method of Sun et al. [20] with the Superoxide Dismutase Assay Kit (Cayman Chemical Company). Tissue samples were homogenized in Tris-HCl containing EDTA (1/10; w/v). SOD activity was inhibited by nitro blue tetrazolium reduction, with xanthine-xanthine oxidase used as a superoxide generator, and 1 international unit (IU) is defined as the amount of enzyme needed to exhibit $50 \%$ dismutation of the superoxide radical. Tissue SOD activity was stated as $\mathrm{U} / \mathrm{mg}$ protein.

\section{Catalase Activity (CAT)}

Catalase activity was determined by Catalase Assay Kit (Cayman Chemical Company). The basis of the method is the reaction of the enzyme with methanol, in the presence of an optimal concentration of $\mathrm{H}_{2} \mathrm{O}_{2}$ [21]. Crayfish tissues were homogenized with $0.05 \mathrm{M}$ phosphate buffer at $\mathrm{pH}$ 7.0. CAT activity was expressed as units representing the calculated rate constant $(\mathrm{K}) / \mathrm{mg}$ protein.

\section{Glutathione Peroxidase Activity (GPx)}

GPx activity was measured according to the protocol of the Glutathione Peroxidase Assay Kit (Cayman Chemical Company). Tissue samples were homogenized in Tris-HCl containing EDTA (1/10; w/v). Tissue Glutathione Peroxidase Activity results were stated as nanomoles of NADPH oxidized per minute per mg protein, using an extinction coefficient for NADPH at $340 \mathrm{~nm}$.

Two replicates were performed for all tests. Besides protein concentrations for all tissues were performed by the method of Lowry et al. [22].

\section{Statistical analyses}

The results are means \pm SD. Analysis of data concerning the differences between groups was made using non-parametric Mann Whitney-U Test and Kruskal Wallis with GRAPHPAD InStat 3 Statistic Programme.

\section{Results}

\section{Haemolymph analysis}

Following exposure to $0.05 \mu \mathrm{g} / \mathrm{L}$ of deltamethrin for $48 \mathrm{~h}$ and 7 days, the THCs values were decreased significantly when compared to control groups ( $\mathrm{p}<0.05)$. Means $(\mathrm{THC} / \mathrm{mL})$ of the control values were 80,989.58 \pm 13,390 and 79,427.08 \pm 9,909 as control and control (solvent), respectively. The decrease was around $27 \%$ after $48 \mathrm{~h}(50,885.42 \pm 3,971.8)$ and $50 \%$ after 7 days $(34,895.83 \pm 3,125.8)$ when compared to control groups. There is no significant difference between duration times of exposure groups. The results are shown in Figure 1.

Haemolymph TAS levels of deltamethrin exposed crayfish were slightly increased when compared to control groups but not statistically significantly different. The haemolymph TAS results are shown in Figure 2. Means of the haemolymph TAS values for control and control (solvent), $48 \mathrm{~h}$ exposed group and 7 days exposed group were $1.50 \pm 0.02,1.52 \pm 0.05,1.60 \pm 0.06$ and $1.57 \pm 0.04 \mathrm{mmol} / \mathrm{L}$, respectively. There was no significant correlation between THCs and TAS $\left(r^{2}=0.045\right)$.

\section{Antioxidant enzyme activities of tissue samples}

SOD enzyme activities of gill tissues were significantly increased when compared to control groups ( $<<0.05$ ). Means of gill tissue SOD enzyme activities for control and control (solvent), $48 \mathrm{~h}$ exposed group and 7 days exposed group were $4.33 \pm 0.42,4.54 \pm 0.89,5.26 \pm 1.04$ and $5.13 \pm 0.45 \mathrm{U} / \mathrm{mg}$ protein, respectively. Gill tissue SOD activities were increased about $17 \%$. SOD activities of

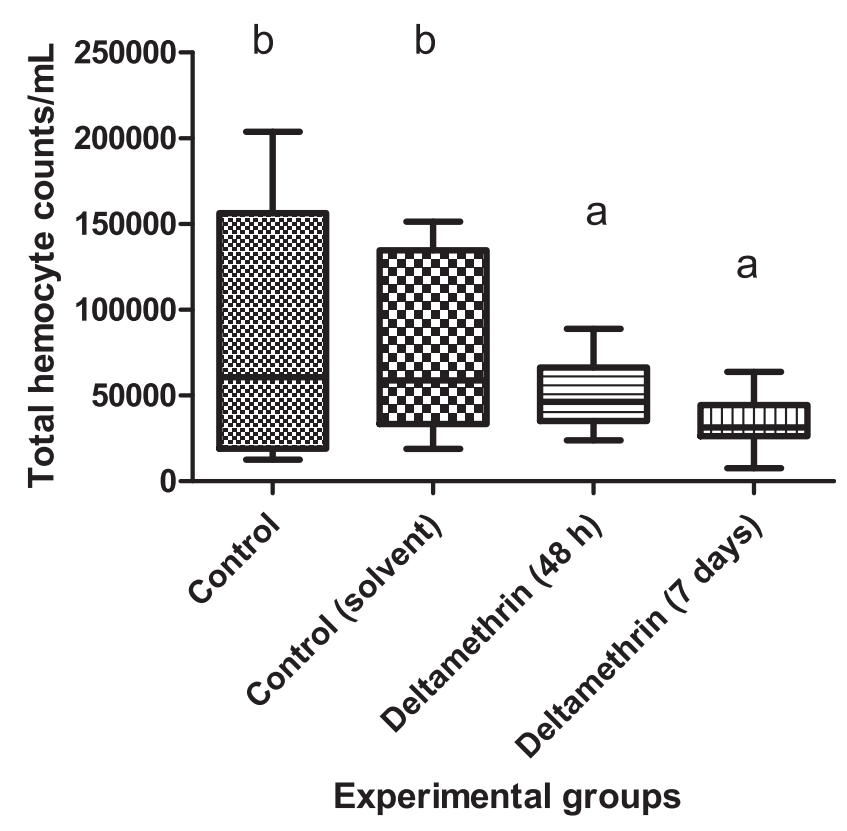

Figure 1: Total haemocyte counts of crayfish after exposure to $0.005 \mu \mathrm{g} / \mathrm{L}$ of deltamethrin for $48 \mathrm{~h}$ and 7 days. Means in the figure with different small letters are significantly different $(p<0.05)$. 


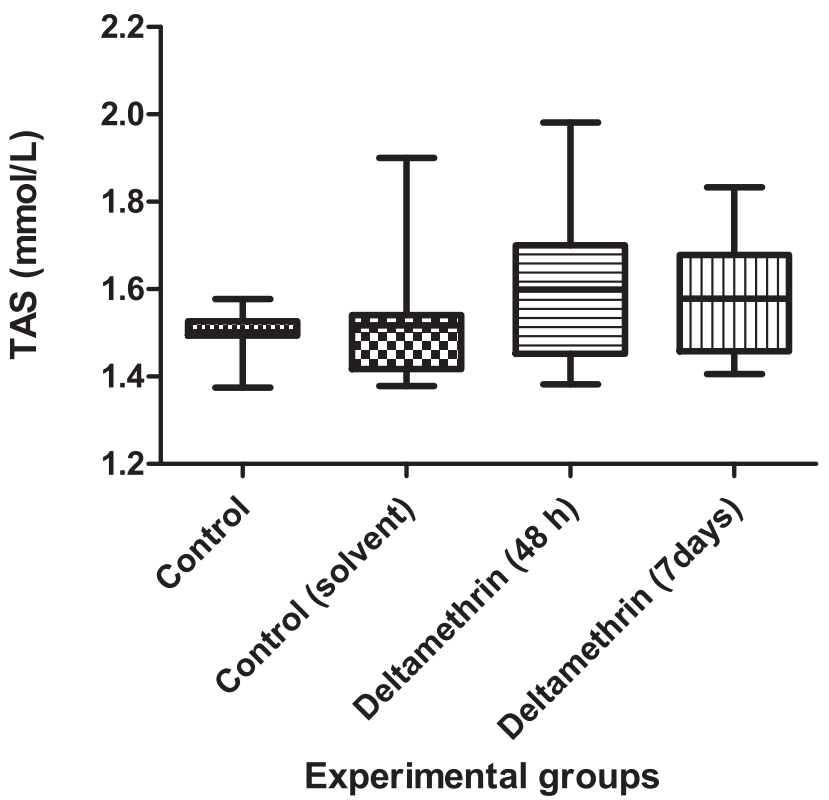

Figure 2: Haemolymph total antioxidant status of crayfish after exposed to $0.005 \mu \mathrm{g} / \mathrm{L}$ of deltamethrin for $48 \mathrm{~h}$ and 7 days.

hepatopancreas tissues were not altered statistically. Means of the hepatopancreas tissue SOD enzyme activities for control and control (solvent), $48 \mathrm{~h}$ exposed group and 7 days exposed group were $1.50 \pm 0.59,1.48 \pm 0.46$, $1.74 \pm 0.34$ and $1.55 \pm 0.23 \mathrm{U} / \mathrm{mg}$ protein, respectively. SOD activities of muscle tissues were significantly rised $(\mathrm{p}<0.05)$ after exposed to deltamethrin. Means of muscle tissue SOD enzyme activities for control and control (solvent), $48 \mathrm{~h}$ exposed group and 7 days exposed group were $3.69 \pm 0.20,3.91 \pm 0.14,5.40 \pm 0.33$ and $4.64 \pm 0.27 \mathrm{U} / \mathrm{mg}$ protein, respectively. The SOD activity results of gill, hepatopancreas and muscle tissues are depicted in Figure 3.

CAT enzyme activities of gill tissues were significantly increased when compared to control groups $(\mathrm{p}<0.05)$. Means of gill tissue CAT enzyme activities for control and control (solvent), $48 \mathrm{~h}$ exposed group and 7 days exposed group were $0.059 \pm 0.024,0.048 \pm 0.001,0.09 \pm 0.003$ and $0.08 \pm 0.001 \mathrm{mmol} / \mathrm{min} / \mathrm{mg}$ protein, respectively. CAT activities were increased about $31 \%$ after $48 \mathrm{~h}$ and $20 \%$ after 7 days. Hepatopancreas CAT levels were increased significantly after $48 \mathrm{~h}(\mathrm{p}<0.05)$, but returned back to control levels after 7 days. Means of hepatopancreas tissue CAT enzyme activities for control and control (solvent), $48 \mathrm{~h}$ exposed group and 7 days exposed group were $0.077 \pm 0.010,0.081 \pm 0.003,0.176 \pm 0.089$ and $0.070 \pm 0.001 \mathrm{mmol} / \mathrm{min} / \mathrm{mg}$ protein, respectively. The CAT activities of muscle tissues were not affected by deltamethrin exposure. Means of muscle tissue CAT enzyme

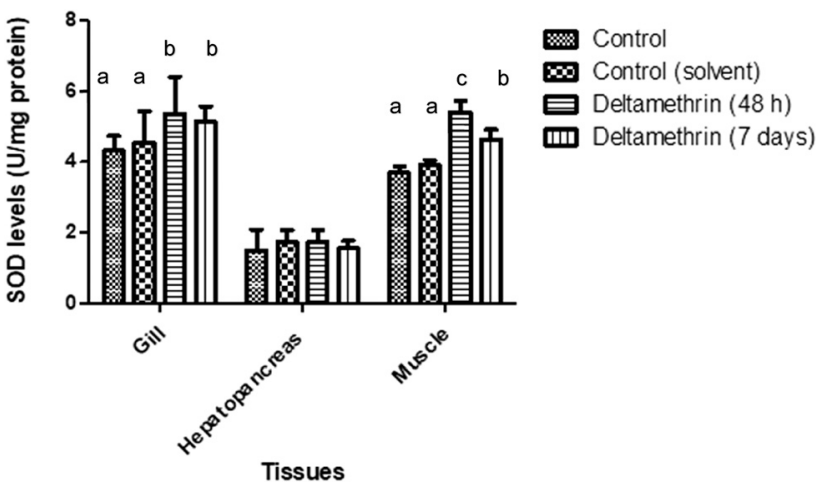

Figure 3: SOD levels of gill, hepatopancreas and muscle tissues of crayfish after exposed to $0.005 \mu \mathrm{g} / \mathrm{L}$ of deltamethrin for $48 \mathrm{~h}$ and 7 days. Means in the figure for each tissue with different small letters are significantly different $(p<0.05)$.

activities for control and control (solvent), $48 \mathrm{~h}$ exposed group and 7 days exposed group were $0.021 \pm 0.05$, $0.022 \pm 0.01,0.020 \pm 0.004$ and $0.019 \pm 0.040 \mathrm{mmol} / \mathrm{min} /$ $\mathrm{mg}$ protein, respectively. The CAT activity results of gill, hepatopancreas and muscle tissues are shown in Figure 4.

GPx enzyme activities of gill tissues were significantly increased when compared to control groups ( $<<0.05)$. Means of gill tissue GPx enzyme activities for control and control (solvent), $48 \mathrm{~h}$ exposed group and 7 days exposed group were $1.136 \pm 0.12,1.120 \pm 0.02,1.48 \pm 0.158$ and $1.831 \pm 0.03 \mathrm{mmol} / \mathrm{min} / \mathrm{mg}$ protein, respectively. GPx activities were increased about $25 \%$ after $48 \mathrm{~h}$ and $38 \%$ after 7 days. Means of hepatopancreas tissue GPx enzyme activities for control and control (solvent), $48 \mathrm{~h}$ exposed group and 7 days exposed group were $0.382 \pm 0.05$, $0.401 \pm 0.01,0.530 \pm 0.193$ and $0.501 \pm 0.039 \mathrm{mmol} / \mathrm{min} /$ $\mathrm{mg}$ protein, respectively. Hepatopancreas GPx activities

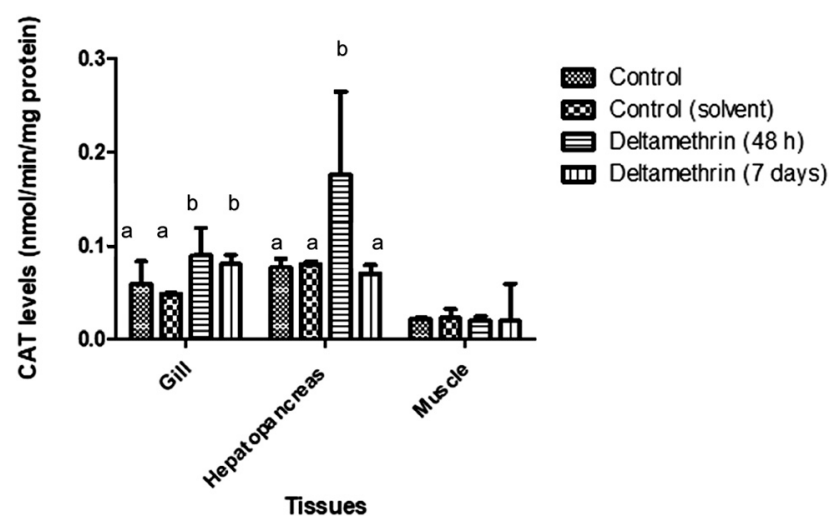

Figure 4: CAT levels of gill, hepatopancreas and muscle tissues of crayfish after exposed to $0.005 \mu \mathrm{g} / \mathrm{L}$ of deltamethrin for $48 \mathrm{~h}$ and 7 days. Means in the figure for each tissue with different small letters are significantly different $(p<0.05)$. 


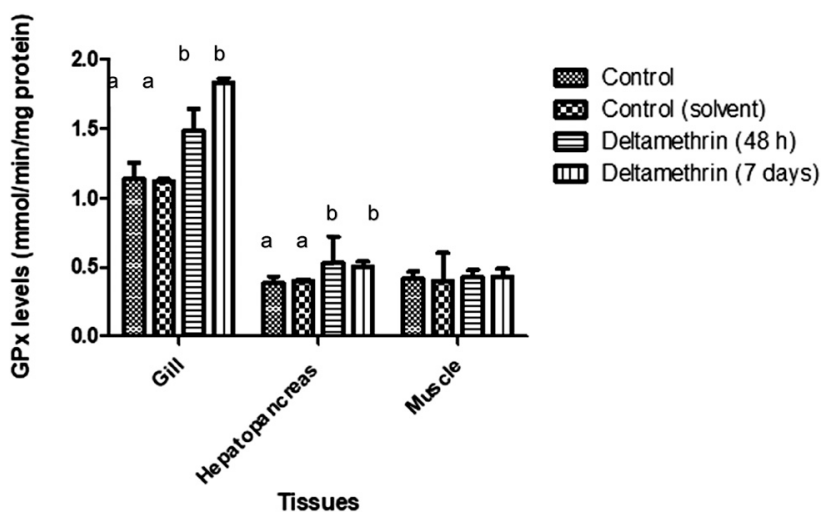

Figure 5: GPx levels of gill, hepatopancreas and muscle tissues of crayfish after exposed to $0.005 \mu \mathrm{g} / \mathrm{L}$ of deltamethrin for $48 \mathrm{~h}$ and 7 days. Means in the figure for each tissue with different small letters are significantly different $(p<0.05)$.

were increased significantly after the exposure to deltamethrin during the both exposure period $(p<0.05)$. Means of muscle tissue GPx enzyme activities for control and control (solvent), $48 \mathrm{~h}$ exposed group and 7 days exposed group were $0.416 \pm 0.05,0.402 \pm 0.20,0.424 \pm 0.052$ and $0.432 \pm 0.055 \mathrm{mmol} / \mathrm{min} / \mathrm{mg}$ protein, respectively. Muscle GPx activities were not altered after deltamethrin exposure. The GPx activity results of gill, hepatopancreas and muscle tissues are shown in Figure 5.

Gill tissues SOD, CAT and GPx activities, hepatopancreas CAT and GPx activities and muscle SOD activities increased significantly compared to control groups $(\mathrm{p}<0.05)$, while hepatopancreas SOD activities and muscle CAT and GPx activities were not altered significantly.

\section{Discussion}

The determination of enzyme activities in aquatic animals are extensively evaluated for monitoring the existence of the contaminants in aquatic ecosystems and sensitive biochemical bioindicators before hazardous effects occur on the food web through humans. The SOD, CAT and GPx activities provide a primary line of defence under stress [23-24]. In recent study, haemocyte numbers were evaluated as stress marker for crayfish and showed that the total number of haemocytes in crayfish, A. leptodactylus significantly decreased following the exposure to $0.05 \mu \mathrm{g} / \mathrm{L}$ of deltamethrin for $48 \mathrm{~h}$ and 7 days.

Decreases in THCs are normally related to several environmental contaminants and stress factors for different crustaceans: Jussila et al. [25], Yildiz and Benli [26] and Smith and Johnston [27], reported significant decline in
THCs in shrimp, Crangon crangon following treatment to Polychlorinated biphenyl. Qin et al. [28]; determined decrease at the THCs of freshwater crab Sinopotamon henanense following exposure to 58 and $116 \mathrm{mg} / \mathrm{L}$ cadmium for $96 \mathrm{~h}$.

TAS is an overall indicator of antioxidant status by representing the enzyme and nonenzyme activities of original antioxidants in the body [29]. As TAS values increase, the antioxidant defence against free radical reaction and reactive $\mathrm{O}_{2}$ intermediates rises [30]. Detection of TAS in aquatic invertebrates have not fully reported in the open literature. So, the results also important and original as the first report about this bioindicator in invertebrate model organisms although we had increased levels for TAS evaluation but not statistically important. In addition, plasma TAS levels have been evaluated as an indicator of stress factors and immune responses at aquatic vertebrates [31-33].

Detection of SOD activity has been widely used as a bioindicator in fish related to health enhancement, monitoring of pollution stress like pesticides, disease indication, and thermal or osmotic stress. However, studies of SOD with crustaceans are limited [34]. In our study, gill and muscle tissues for SOD enzyme activities were significantly increased, while hepatopancreas SOD activities did not alter. SOD detoxifies the superoxide anion $\left(\mathrm{O}_{2}-\right)$ forming hydrogen peroxide $\left(\mathrm{H}_{2} \mathrm{O}_{2}\right)$ and the latter, as a ROS, is decomposed by CAT and GPx [35]. Deltamethrin induce toxic effect in aquatic organisms through their high rate of gill absorption, lipophilicity and deficiency in the fish enzyme system to hydrolyse pyrethroids [36]. Borkovic et al. [37] determined lower total SOD activities in the hepatopancreas compared to the gills SOD activities of muscle Spiny cheek crayfish (Orconectes limosus) at the River Danube. Similar to our results, the elevated activity of SOD in the gill tissue was observed in crayfish after exposed to carbaryl for $48 \mathrm{~h}$ and 7 days [38].

The CAT and GPX activity in the present study was significantly increased in the gill tissue in both exposure times while no changes were observed for muscle tissue. Similar to our results, CAT activities were changed in crayfish after exposed to 0.144 and $1.44 \mathrm{mg} / \mathrm{L}$ prometryne at 11 days [39]. CAT activities were increased in the hepatopancreas tissue than in the gill tissues of crayfish from River Danube [37]. Fernandez et al. [40] and Benli et al. [38] determined high CAT activity after exposure to $48 \mathrm{~h}$ carbamate pesticide of carbaryl. In different studies, the increased GPx activity in the hepatopancreas tissue of two different crayfish species after exposed to carbaryl were also observed [38, 40]. 
As a result, for most ecotoxicologic bioindicators biochemical biomarkers are popular findings, here in our study crayfish as an invertebrate model might be useful candidates for comparative researches with mammals related with biochemical markers. Some of the special features of crustaceans might be important for the interpretation of data from bioindicator studies for developing of ecotoxicological endpoints.

Acknowledgements: This study was supported by Gazi University Scientific Project Unit with Project no: 18/2010-01.

Conflict of interest: Authors declare no conflict of interest. Çıkar çatışması: Yazarlar çıkar çatışması bildirmemişlerdir.

\section{References}

1. Sumpter JP. Protecting aquatic organisms from chemicals: the harsh realities. Philos Trans R Soc A 2009;367:3877-89. https:// doi.org/10.1098/rsta.2009.0106.

2. Parvez S, Raisuddin S. Copper modulates non-enzymatic antioxidants in the freshwater fish Channa punctata (Bloch) exposed to deltamethrin. Chemosphere 2006;62:1324-32. https://doi.org/10.1016/j.chemosphere.2005.07.025.

3. Smith TM, Stratton. GW. Effects of synthetic pyrethroid insecticides on nontarget organisms. Res Rev 1986;97:93-119. https://doi.org/10.1007/978-1-4612-4934-4_4.

4. Rehman H, Ali M, Atif F, Kaur M, Bhatia K, Raisuddin K. The modulatory effect of deltamethrin on antioxidants in mice. Clin Chem Acta 2006;369:61-65. https://doi.org/10.1016/j.cca. 2006.01.010.

5. Yalın S, Çömelekoğlu Ü, Mazmancı B, Ballı E, Eroğlu P, Sögüt F, et al. Effect of Funalia trogii in heart tissue of rats exposed to deltamethrin. Turk J of Biochem 2012;37:239-44. https://doi. org/10.5505/tjb.2012.52724.

6. Oliveira C, Almeida J, Guilhermino L, Soares AMVM, Gravato C. Acute effects of deltamethrin on swimming velocity and biomarkers of the common prawn Palaemon serratus. Aquat Toxicol 2012;124-125:209-16. https://doi.org/10.1016/j. aquatox.2012.08.010.

7. Velisek J, Dobsikova R, Svobodova Z, Modra H, Luskova V. Effect of deltamethrin on the biochemical profile of common carp (Cyprinus carpio L.). Bull Environ Contam Toxicol 2006;76: 992-8. https://doi.org/10.1007/s00128-006-1016-9.

8. Sayeed I, Parvez S, Pandey S, Hafeez B, Haque R, Raisuddin S, et al. Oxidative stress biomarkers of exposure to deltamethrin in freshwater fish, Channa punctatus Bloch. Ecotox Environ Saf 2003;56:295-301. https://doi.org/10.1016/s0147-6513(03) 00009-5.

9. Banerjee BD, Seth V, Ahmed RS. Pesticide-induced oxidative stress: perspectives and trends. Rev Environ Health 2001;16:1-40. https://doi.org/10.1515/reveh.2001. 16.1.1.

10. Abdollahi M, Ranjbar A, Shadnia S, Nikfar S, Rezaiee A. Pesticides and oxidative stress: a review. Med Sci Monit 2004;10:141-7.
11. Fiorino E, Sehonova P, Ihalova L, Blahova J, Svobodova Z, Faggio C. Effects of glyphosate on early life stages: comparison between Cyprinus carpio and Danio rerio. Environ Sci Pol Res 2018;25: 8542-9. https://doi.org/10.1007/s11356-017-1141-5.

12. Burgos-Aceves MA, Cohen A, Smith Y, Faggio C. MicroRNAs and their role on fish oxidative stress during xenobiotic environmental exposures. Ecotox Environ Saf 2018;148: 995-1000. https://doi.org/10.1016/j.ecoenv.2017.12.001.

13. Sehonova P, Svobodova Z, Dolezelova P, Vosmerova P, Faggio C. Effects of waterborne antidepressants on non-target animals living in the aquatic environment: a review. Sci of the Total Environ 2018;631-632:789-94. https://doi.org/10.1016/j. scitotenv.2018.03.076.

14. Kumar A, Sasmal D, Sharma N. Mechanism of deltamethrin induced thymic and splenic toxicity in mice and its protection by piperine and curcumin: In vivo study. Drug Chem Toxicol 2018;41: 33-41. https://doi.org/10.1080/01480545.2017.1286352.

15. Sepici-Dinçel A, Alparslan N, Benli ACK, Selvi M, Sarıkaya R, Özkul IA, et al. Haemolymph biochemical parameters reference intervals and total haemocyte counts of narrow clawed crayfish Astacus leptodactylus (Eschscholtz, 1823), Ecol Indicat 2013;24: 305-9. https://doi.org/10.1016/j.ecolind.2012.07.002.

16. Köksal G. Astacus leptodactylus in Europe. In: Holdich DM, Lowery R, editors. Freshwater crayfish biology, management and exploitation. London, UK: Croom Helm; 1988:365-400 pp.

17. Meng L, Meyer PNR, Leary ML, Mohammed YF, Ferber SD, Lin JW, et al. Effects of Deltamethrin on crayfish motor axon activity and neuromuscular transmission. Neurosci Lett 2016;617:32-8. https://doi.org/10.1016/j.neulet.2016.01.061.

18. Benli ACK. The influence of etofenprox on narrow clawed crayfish (Astacus leptodactylus Eschscholtz, 1823): Acute toxicity and sublethal effects on histology, haemolymph parameters, and total haemocyte counts. Environ Toxicol 2015;30:887-94. https://doi.org/10.1002/tox.21963.

19. Miller NJ, Rice-Evans C, Davies MJ, Gopinathan V, Milner A. A novel method for measuring antioxidant capacity and its application to monitoring the antioxidant status in premature neonates. Clin Sci (Lond) 1993;84:407-12. https://doi.org/10.1042/cs0840407.

20. Sun Y, Oberley LW, Li YA. Simple method for clinical assay of superoxide dismutase. Clin Chem 1988;34:497-500.

21. Aebi H. Catalase in vitro. Methods Enzymol 1984;105:121-6.

22. Lowry OH, Rosebrough HJ, Farr AL, Randall RJ. Protein measurement with the Folin phenol reagent. J Biol Chem 1951; 193:265-75.

23. Schvezov N, Gustavo A, Lovrich M, Romero C. Oxidative stress during re-immersion of the king crab Lithodes santolla (Molina, 1782) (Decapoda: Anomura: Lithodidae) after air exposure. J Crustac Biol 2017;37:195-203. https://doi.org/10.1093/jcbiol/ rux004.

24. Stara A, Kouba A, Velisek J. Effect of chronic exposure to prometryne on oxidative stress and antioxidant response in red swamp crayfish (Procambarus clarkii). J Biomed Biotec 2014;1: 680131. https://doi.org/10.1155/2014/680131.

25. Jussila J, Jago J, Tsvetnenko E, Dunstan B, Evans LH. Total and differential haemocyte counts in western rock lobsters (Panulirus cygnus George) under postharvest stress. Mar Freshwater Res 1997;48:863-7.

26. Yildiz H, Benli ACK. Nitrite toxicity to crayfish, Astacus leptodactylus, the effects of sublethal nitrite exposure on hemolymph nitrite, total hemocyte counts, and hemolymph 
glucose. Ecotox Environ Saf 2004;59:370-5. https://doi.org/10. 1016/j.ecoenv.2003.07.007.

27. Smith VJ, Johnston PA. Differential haemotoxic effect of PCB congeners in the common shrimp, Crangon crangon. Comp Biochem Physiol C 1992;101:641-9. https://doi.org/10.1016/ 0742-8413(92)90099-s.

28. Qin Q, Qin S, Wang L, Lei W. Immune responses and ultrastructural changes of haemocytes in freshwater crab Sinopotamon henanense exposed to elevated cadmium. Aquat Toxicol 2012;106-107:140-6. https://doi.org/10.1016/j. aquatox.2011.08.013.

29. Xiao N, Wang XC, Diao YF, Liu R, Tian KL, Effect of initial fluid resuscitation on subsequent treatment in uncontrolled hemorrhagic shock in rats. Shock 2004;21:276-80. https://doi. org/10.1097/01.shk.0000110622.42625.cb.

30. Chien YH., Pan CH, Hunter B. The resistance to physical stresses by Penaeus monodon juveniles fed diets supplemented with astaxanthin. Aquaculture 2003;216:177-91. https://doi.org/10. 1016/S0044-8486(02)00056-X.

31. Selvi M, Cavaş T, Benli ACK, Koçak Memmi B, Cinkılıç N. Sublethal toxicity of esbiothrin relationship with total antioxidant status and in vivo genotoxicity assessment in fish (Cyprinus carpio L., 1758) using the micronucleus test and comet assay. Environ Toxicol 2013; 28:644-51. https://doi.org/10.1002/tox.20760.

32. Lushchak VI. Free radicals, reactive oxygen species, oxidative stress and its classification. Chem Biol Interact 2014;224: 164-75. https://doi.org/10.1016/j.cbi.2014.10.016.

33. Gobi N, Vaseeharan B, Rekha R, Vijayakumar S, Faggio C. Bioaccumulation, cytotoxicity and oxidative stress of the acute exposure selenium in Oreochromis mossambicus. Ecotoxicol Environ Saf 2018;162:147-59. https://doi.org/10.1016/j.ecoenv.2018.06.070.
34. Holmblad T, Söderhäll K. Cell adhesion molecule and antioxidation enzymes in a crustacean, possible role in immunity. Aquaculture 1999;172:111-23. https://doi.org/10. 1016/S0044-8486(98)00446-3.

35. Bell KL, Smith VJ. In vitro superoxide production by hyaline cells of the shore crab Carcinus maenas (L.). Dev Comp Immunol 1993; 17:211-19. https://doi.org/10.1016/0145-305X(93)90040-W.

36. Viran R, Erkoç FÜ, Polat $H$, Koçak 0 . Investigation of acute toxicity of deltamethrin on guppies Poecilia reticulate. Ecotoxicol Environ Saf 2003;55:82-5. https://doi.org/10.1016/s0147-6513(02) 00096-9.

37. Borkovic SS, Pavlovic SZ, Kovacevic TB, Stajn AS, Petrovic VM, et al. Antioxidant defence enzyme activities in hepatopancreas, gills and muscle of Spiny cheek crayfish (Orconectes limosus) from the River Danube. Comp Biochem Phys C 2008;147:122-8. https://doi.org/10.1016/j.cbpc.2007.08.006.

38. Benli ACK, Şahin D, Koçak B, Sepici Dinçel A, Karbarile maruz kalan tatlı su istakozlarında (Astacus leptodactylus Eschscholtz, 1823) antioksidan enzim düzeyleri. Turk J Bioch 2012;37:162-6. https://doi.org/10.5505/tjb.2012. 24633.

39. El-Atti AM, Mahmoud MA, Desouky MA, Mohamadien A, Radwa MS. Effects of titanium dioxide nanoparticles on red swamp crayfish, Procambarus clarkii: Bioaccumulation, oxidative stress and histopathological biomarkers. Egypt J Aquat Res 2019;45: 11-18. https://doi.org/10.1016/j.ejar.2019.01.001.

40. Fernández AV, de Almeida EA, López-Barea J. Biochemical and proteomic effects in Procambarus clarkii after chlorpyrifos or carbaryl exposure under sublethal conditions. Biomarkers 2009;14:299-310. https://doi.org/10.1080/ 13547500902913211. 